Article

\title{
Bird Species Involved in West Nile Virus Epidemiological Cycle in Southern Québec
}

\author{
Ludivine Taieb ${ }^{1,2}$, Antoinette Ludwig 1,3,*, Nick H. Ogden ${ }^{1,3}$, Robbin L. Lindsay ${ }^{4}$, \\ Mahmood Iranpour ${ }^{4}$, Carl A. Gagnon ${ }^{2,5}$ and Dominique J. Bicout $6,7, *$ (D)
}

1 Research Group on Epidemiology of Zoonoses and Public Health (GREZOSP), Faculty of Veterinary Medicine, Université de Montréal, Saint-Hyacinthe, QC J2S 2M2, Canada; ludivine.taieb@gmail.com (L.T.); nicholas.ogden@canada.ca (N.H.O.)

2 Department of Pathology and Microbiology, Faculty of Veterinary Medicine, Université de Montréal, Saint-Hyacinthe, QC J2S 2M2, Canada; carl.a.gagnon@umontreal.ca

3 Public Health Risk Sciences Division, National Microbiology Laboratory, Public Health Agency of Canada (PHAC), Saint-Hyacinthe, QC J2S 2M2, Canada

4 Zoonotic Diseases and Special Pathogens Division, National Microbiology Laboratory, Public Health Agency of Canada (PHAC), Winnipeg, MB R3E 3R2, Canada; robbin.lindsay@canada.ca (R.L.L.);

mahmood.iranpour@canada.ca (M.I.)

5 Swine and Poultry Infectious Diseases Research Center (CRIPA), Faculty of Veterinary Medicine, Université de Montréal, Saint-Hyacinthe, QC J2S 2M2, Canada

6 Biomathématiques et Épidémiologie, EPSP-TIMC, UMR CNRS 5525, Université Grenoble-Alpes, VetAgro Sup, 38700 La Tronche, France

7 Laue-Langevin Institute, Theory Group, 71 Avenue des Martyrs, 38042 Grenoble, France

* Correspondence: antoinette.ludwig@canada.ca (A.L.); bicout@ill.fr (D.J.B.); Tel.: +33-673-267-496 (D.J.B.)

Received: 21 May 2020; Accepted: 18 June 2020; Published: 23 June 2020

\begin{abstract}
Despite many studies on West Nile Virus (WNV) in the US, including the reservoir role of bird species and the summer shifts of the Culex mosquito, feeding from birds to mammals, there have been few equivalent studies in the neighboring regions of Canada where WNV is endemic. Here, a priority list of bird species likely involved in WNV transmission in the greater Montréal area is constructed by combining three sources of data: (i) from WNV surveillance in wild birds (2002-2015); (ii) blood meal analysis of Culex pipiens-restuans (CPR), the primary enzootic vectors of WNV in the region, collected from surveillance in 2008 and 2014; (iii) literature review on the sero-prevalence/host competence of resident birds. Each of these data sources yielded 18, 23 and 53 species, and overall, 67 different bird species were identified as potential WNV amplifiers/reservoirs. Of those identified from CPR blood meals, Common starlings, American robins, Song sparrows and House sparrows ranked the highest and blood meal analysis demonstrated a seasonal shift in feed preference from birds to mammals by CPR. Our study indicates that there are broad similarities in the ecology of WNV between our region and the northeastern US, although the relative importance of bird species varies somewhat between regions.
\end{abstract}

Keywords: West Nile; wild birds; Culex feeding/host preference; eco-epidemiology; Québec

\section{Introduction}

First described in Uganda in 1937 [1], West Nile Virus (WNV) is an arbovirus of the Flaviviridae virus family, genus Flavivirus. It has a transmission cycle involving mosquitoes as vectors and birds as amplifying hosts or reservoirs, with humans and horses being primarily dead-end hosts [2,3]. In humans, the early symptoms of WNV include fever, headache, skin rash, nausea and muscle aches. Most of the affected people recover fully, but approximately $1 \%$ develops severe illness (meningitis, 
encephalitis, acute flaccid paralysis and poliomyelitis) [4]. Those over 70 years of age with underlying medical conditions and those who are immuno-compromised are at a greater risk of severe illness [4]. In North America, the first WNV outbreak occurred in New York in 1999, and WNV spread rapidly across the continent, causing mortality in many bird species [5-7]. In less than four years, the virus spread to most of the continental United States, and its activity was first reported in Canada in 2001 [8]. WNV is now endemic in much of southern Canada and, given the potential severity of the disease in humans and the lack of treatment or a specific vaccine, WNV infection is a major public health concern in Canada, including in the province of Québec [9]. Most human cases of WNV reported in Canada occur in Québec, Ontario and the Prairie provinces, and the intensities of the outbreaks of WNV vary temporarily and spatially, as shown in Figure 1. In Québec, human cases of WNV are mainly reported from the Montérégie, Montréal and Laval regions of southern Québec [9]. This study focuses on the Montréal area, one of the regions most affected by WNV in Québec, with 28\% of the clinical cases of WNV reported between 2002 and 2014 [9].

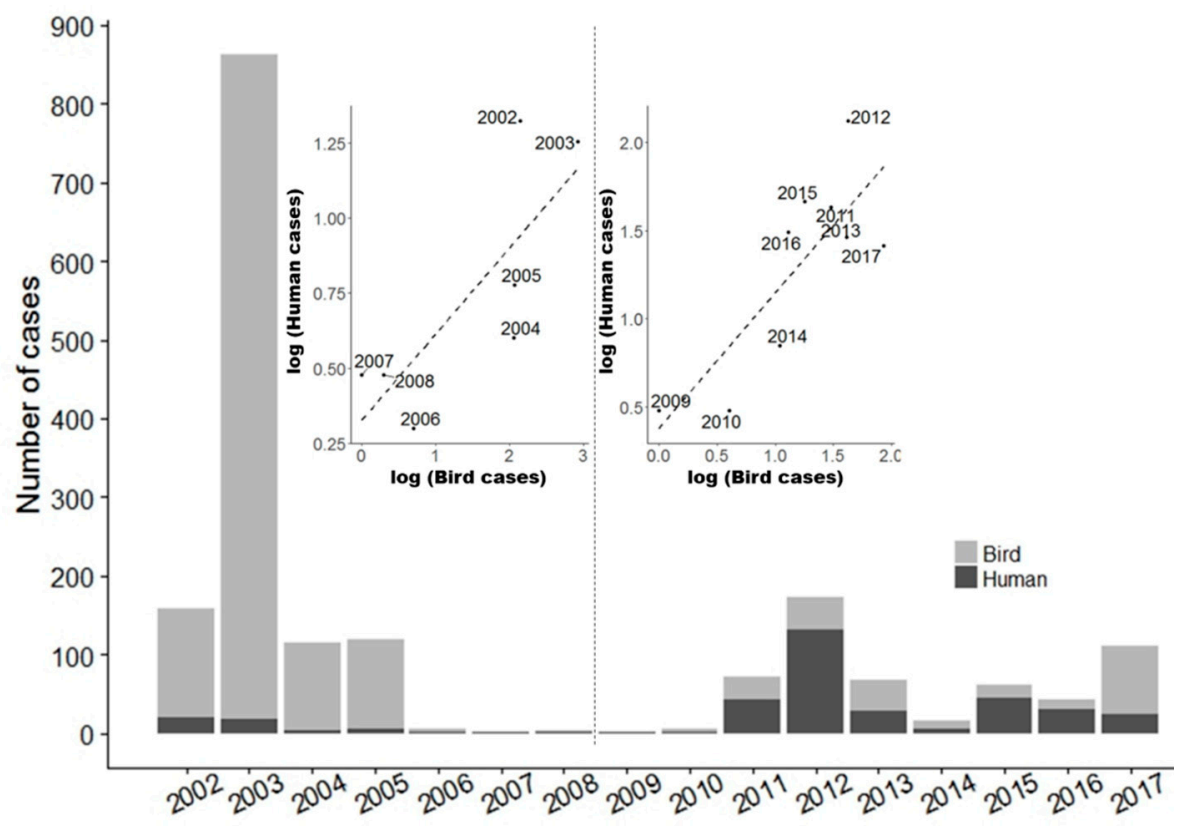

Figure 1. Yearly number of cases of West Nile virus (WNV) infection in humans and number of dead birds positive to WNV in Québec 2002-2017. Insert: Correlation between the number of WNV bird and human cases in Québec.

The epizootiological cycle of WNV transmission involves bird of several species that act as reservoirs/amplifying hosts and a range of mosquito species that transmit the virus amongst animals (enzootic vectors) and/or to humans (epizootic vectors). Mammals, such as horses and humans, are incidental or dead-end hosts that are not part of the virus transmission cycle because they do not produce viremia sufficient to infect mosquitoes [10]. In southeastern Canada, including Québec, the main WNV enzootic vectors are Culex pipiens and Culex restuans [11] and these species are also involved in the transmission of WNV to humans in neighboring parts of the northeastern US [12-14].

A range of bird species can act as reservoir hosts for WNV, and annual migration by many species disperses WNV over long distances [15-19]. The importance of birds species as amplifying hosts depends on a combination of factors: (i) the susceptibility to infection; (ii) the duration of viremia at levels high enough to infect feeding mosquitoes; (iii) the density of naïve individuals (a combination of the density of the species and rates of infection followed by protective immunity); (iv) the "attractiveness" of the species to (ornithophilic and opportunistic) mosquito vectors and thus the proportion of mosquito bites per unit of space-time that occur on the species; and, (v) the rates of mortality, including WNV-specific mortality, of infected individuals. 
Experimental studies have shown that several North American bird species are susceptible to WNV and can transmit the virus because they produce a level of viremia that is sufficient to infect mosquitoes that feed upon them-some species die as a result of this infection [20]. Mortality in wild bird populations, particularly corvids, was used as an early surveillance signal of WNV activity in a given locality, as the virus first spread across the US and then Canada [21,22]. Wild bird mortality was also used as an index of the rates of expected human cases of WNV [23]. Retrospective analysis suggested that, when it first invaded North America, WNV caused mortality in a wide range of bird species [24].

Studies in the US have taken into account the multiple factors that define reservoir competence, and by combining field observations and laboratory experiment results, they conclude that the American robin is a key reservoir species [12]. Furthermore, studies from the US suggest that the seasonal nature of human WNV cases (with most cases from late summer through to mid-autumn) is associated with a shift in mosquito blood meals from birds to mammals during the high-risk period, which may be driven by birds beginning their southward migration at this time [13]. To date, similar studies on the transmission dynamics of WNV in Canada are lacking.

In this study, we aimed to develop a priority list of bird species likely involved in the circulation of WNV in the region of Montréal in southern Québec, Canada. To do so we scanned the literature and dead bird surveillance data to identify bird species that breed in the region and are known to be competent WNV amplifiers/reservoirs. We also prioritized these species according to field and laboratory data on the feeding preferences of Culex pipiens-restuans (CPR) mosquitoes, while accounting for bird species abundance in the Montréal area. The blood meal analysis data also allowed us to explore the occurrence of seasonal shifts in the host-feeding behavior of key species of vector mosquitoes. Collectively this data allowed us to determine the bird species that are key amplifier/reservoir hosts for $\mathrm{WNV}$ and to determine the extent to which host shifting occurs in vector mosquitoes in Québec.

\section{Materials and Methods}

\subsection{Study Area}

The greater Montréal area is located in the southern Québec, as shown in Figure 2, and in the central part of the St. Lawrence Lowlands. The region is bordered to the north by the Canadian Shield and to the southeast by the Appalachians [25]. The region is characterized by a temperate continental climate, with cold winters and hot summers [25]. The study area is $30,231.2 \mathrm{~km}^{2}$, and includes the island of Montréal and was limited by the coordinates $46^{\circ} 13^{\prime} 48 \mathrm{~N}, 45^{\circ} 1^{\prime} 12 \mathrm{~N}$ and $74^{\circ} 24^{\prime} 36 \mathrm{~W}$ and $72^{\circ} 23^{\prime} 24$ W. In 2011, the greater Montréal area was comprised of $21 \%$ buildings, $40 \%$ cultivated agricultural land and 39\% natural or semi-natural areas, of which $66 \%$ was forest [26]. With 2,900,000 inhabitants, about $45 \%$ of the Québec province's population, the greater Montréal area is the most densely populated area in Québec and the second most densely populated city in Canada.

\subsection{Identification of Priority List of Wild Bird Reservoir Species}

To construct the list of bird species that are possible WNV amplifier and reservoir host in our study area, we used an approach by successive augmentation. Starting with a reference list of regional breeding bird species $L_{0}$, the priority list $L_{f}$ of birds that could potentially play a role in the WNV transmission cycle was obtained as, $L_{f}=L_{0} \cap\left[L_{1}+L_{2}+L_{3}-L_{1} \cap L_{2}-L_{1} \cap L_{3}-L_{2} \cap L_{3}+L_{1} \cap L_{2} \cap L_{3}\right]$, where $\cup$ indicates the "union" of data from databases (bringing all species from the databases together), and $\cap$ indicates the "intersection" of data from the databases (i.e., where species are in the different databases). $L_{1}, L_{2}$ and $L_{3}$ are, respectively, the "databases" of: (i) species identified as infected by WNV in dead bird surveillance; (ii) species identified as being targets for CPR blood meals on the basis of blood meal analyses; (iii) species identified as WNV reservoirs by literature review. In summary, $L_{1}$ is the first basic list that is augmented with species from $L_{2}$ and $L_{3}$ not already in $L_{1}$. The comparison with $L_{0}$ is a check to ensure that selected bird species are found in the study area. $L_{0}$ comprised 318 species 
extracted from the Avibase database [27], which includes all breeding species in the Montréal area. Species reported as rare $(n=65)$ in the Avibase were excluded from $L_{0}$. Details on $L_{1}, L_{2}$ and $L_{3}$ are described in the sub-sections below.

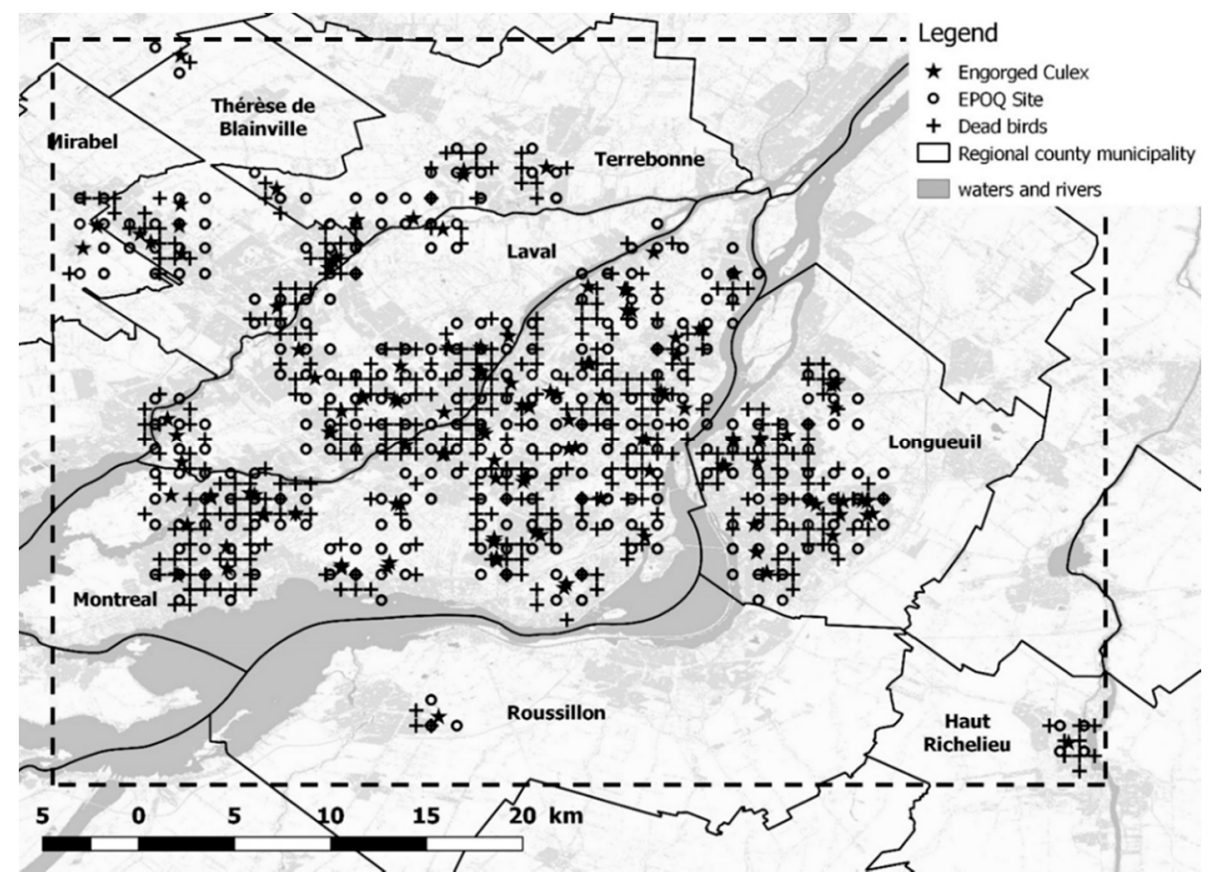

Figure 2. Study area with locations of collection of dead birds (CWHC), bird watching and counts (EPOQ) and collection of engorged female Culex pipiens-restuans on the island of Montréal, Québec.

\subsubsection{Wild Bird Mortality Data: List $\mathrm{L}_{1}$}

Wild bird mortality data were obtained from the Canadian Wildlife Health Cooperative (CWHC) Passive Mortality Monitoring Program [28], and data specific to WNV mortality were acquired from the passive WNV wild bird surveillance program, which was established in 2001, the first year that WNV was detected in Canada [29]. This "passive" surveillance work was carried out in collaboration with the local population, which was invited to report dead bird sights to the relevant authorities. Dead birds were retrieved and submitted to veterinary diagnostic laboratories [29]. In these laboratories, necropsies were performed, and selected tissues were tested for WNV $[29,30]$. The data cover the period 2002-2015, during which time two WNV epidemics occurred in Québec. The locations where dead WNV-infected birds were collected are reported in Figure 2. To rank birds species belonging to $L_{1}$, the standardized mortality ratio, or relative ratio, $R R_{S}$, for each bird species "s" was calculated as, $R R_{s}=m_{s} /\left(\lambda \times n_{s}\right)$, where $m_{s}$ is the number of dead birds of species " $\mathrm{s}$ " found positive for WNV, $n_{s}$ is the corresponding sample size and $\lambda=\sum_{s} m_{s} / \sum_{s} n_{s}$, is the mortality rate under the homogeneous hypothesis; $\left(\lambda \times n_{s}\right)$ is the expected number of dead birds of species "s".

\subsubsection{Blood Meal Data: List $\mathrm{L}_{2}$}

Mosquitoes were collected in our study region between 2008 and 2014 as part of a provincial mosquito surveillance program conducted in southern Québec [9]. Blood meal analysis was conducted only on engorged females of either the Culex pipiens or $C x$. restuans $(C P R)$ complex in this study. The capture sites of engorged females are shown in Figure 2. The list $L_{2}$ consists of bird species identified as blood meal sources for CPR complex mosquitoes. Note that females of Culex pipiens and $C x$. restuans cannot be reliably differentiated morphologically, so the specimens were grouped together as $C P R$ complex mosquitoes. 
Blood-fed mosquitoes were stored individually in $1.5 \mathrm{~mL}$ tubes at $-80{ }^{\circ} \mathrm{C}$ until processing. The extraction of DNA was carried out using a protocol described by Molaei et al. [31]. Briefly, $200 \mu \mathrm{l}$ of DNAzol ${ }^{\circledR}$ BD (Molecular Research Center, Cincinnati, OH, USA) was added to each tube. The mosquitoes were homogenized with a pestle, followed by the addition of another $200 \mu \mathrm{L}$ DNAzol $\mathrm{BD}$ and $15 \mu \mathrm{L}$ proteinase- $\mathrm{K}$. The tubes were vortexed briefly, incubated at $70{ }^{\circ} \mathrm{C}$ for ten minutes, then centrifuged for ten minutes at 14,000 rpm. The supernatants were transferred to new $1.5 \mathrm{~mL}$ tubes and $3 \mu \mathrm{L}$ polyacryl carrier (Molecular Research Center, Cincinnati, $\mathrm{OH}, \mathrm{USA}$ ) was added to each tube. The tubes were incubated at room temperature for three minutes and then $200 \mu \mathrm{L} 100 \%$ ethanol was added. Following mixing by gentle inversion, the tubes were incubated on ice for ten minutes, then centrifuged for six minutes at $6000 \mathrm{rpm}$. The supernatants were removed, and the remaining DNA pellets were washed twice with the addition of $750 \mu \mathrm{L} 75 \%$ ethanol and two minutes of centrifugation at $3000 \mathrm{rpm}$. After the final removal of the ethanol, the tubes were left open to allow the DNA pellets to air dry. Once dry, the pellets were re-suspended in 20 to $50 \mu \mathrm{L} 1 \times$ TE buffer. The DNA extracts obtained from blood-fed mosquitoes were used as templates for the amplification of the cytochrome $b$ gene in avian and mammalian species using primers previously described by Molaei et al. [31]. The extracted DNA was amplified in $50 \mu \mathrm{L}$ reactions using the Platinum taq DNA polymerase system (Invitrogen, Carlsbad, CA, USA) with final concentrations of $1.5 \mathrm{mM} \mathrm{MgCl}_{2}, 200 \mathrm{nM}$ dNTP and 200 $\mathrm{nM}$ per primer. Amplification was carried out in the Applied Biosystems GeneAmp PCR System 9700 using the following conditions: denaturation for two minutes at $94{ }^{\circ} \mathrm{C}, 40$ cycles of amplification consisting of $30 \mathrm{~s}$ at $94{ }^{\circ} \mathrm{C}, 50 \mathrm{~s}$ at $55^{\circ} \mathrm{C}$ (mammalian) or $60^{\circ} \mathrm{C}$ (avian), $60 \mathrm{~s}$ at $72{ }^{\circ} \mathrm{C}$, extension for seven minutes at $72{ }^{\circ} \mathrm{C}$ and then held at $4{ }^{\circ} \mathrm{C}$. The first 100 amplification products were visualized by gel electrophoresis on $1.9 \%$ agarose gel, whereas the remaining samples were run on QIAxcel (Qiagen, Toronto, TO, Canada). Positive samples were purified using the Wizard SV Gel and PCR Clean-up system (Promega, Madison, WI, USA), and Sanger sequencing was performed by the NML Genomics Core Facility using Applied Biosystems 3730 xl DNA Analyzer with Big Dye Terminator version 3.1 and pop7 chemistries. The sequence data were analyzed using DNASTAR Lasergene 9 software and compared to those in the GenBank (NCBI). Since the technology used does not allow for the accurate identification of mixed blood meals, the sequence data from mosquitoes that took multiple host blood meals from different species did not lead to identifiable host species. However, we expected that these events would be rare because adult female $C P R$ typically complete feeding on a one host.

Identified bird species (see Results section) are characterized by the proportion $f_{s}$, defined as the ratio of CPR blood meals taken from the species $s$ divided by the CPR blood meals from all identified bird species. The value of $f_{s}$ depends both on the relative density of species $s$ and on the degree to which a species may be particularly attractive to the mosquitoes-if so, then mosquito bites on a particular species may be disproportionate to the density of the species. To explore this, a feeding preference index can be obtained as [32]: $p_{s}=f_{s} / a_{s}$, where $f_{s}$ is as defined above and $a_{s}$ is the ratio of the abundance of species $s$ over that of the total density of the birds in the area. Such a $p_{s}$ can be regarded as the relative risk for a given bird species of being bitten by the mosquito in relation to its relative abundance [32]. Unfortunately, $p_{s}$ gets larger and tends to infinity when $a_{s}$ tends to zero. Therefore, we use the following definition for the preference index [33,34]: $p_{s}=a_{s} f_{s} / \sum_{j=1}^{n} a_{j} f_{j}$, where $n$ is the total number of bird species identified from CPR blood meals. Likewise, the relative risk for a given bird species of being bitten by the mosquito, relative to homogeneous abundance, is $R R_{s}=n \times p_{s}$. Bird species bitten more or less often than chance are characterized by $R R_{s}>1$ and $R R_{s}<1$, respectively.

Values for $a_{s}$ were obtained from wild bird count data, taken from the EPOQ-ebird database, managed, in part, by the Regroupement Québec Oiseaux (RQO) for the years 2001 to 2016 [35]. This database contains more than six million observations made by ornithologists during their daily bird watching trips within Québec. These data are obtained from opportunistic sampling-each observer records the species observed, as well as the number of individuals of each species seen. These sets of observations correspond to an observation site at a given date during a given period of time, 
as well as to the number of individuals of each species observed. Locations at which bird counts were made are shown in Figure 2.

Analysis of Seasonal Bird-to-Mammal Feeding Shift of CPR Mosquitoes

Culex mosquitoes are classified as ornithophilic species (i.e., mainly feeding on birds) $[13,21,36]$. We investigated whether the feeding preferences of the mosquitoes changed over the activity season. We considered the fraction (or probability $\pi_{b i r d}$ ) of blood meals taken on bird species (i.e., number of blood meals on all bird species only/total number of blood meals over all species (birds and mammals)) as a function of the week of the year. Logistic regression was used to model the variation of the feeding preferences over weeks as follows: $\log i t\left(\pi_{b i r d}\right)=\beta_{0}+\beta_{1}$ week. Statistical analyses were performed using the GLM (generalized linear model) function in R, version 1.1.383 [37].

\subsubsection{Literature Review: List $\mathrm{L}_{3}$}

Literature research was conducted in August 2017 in five electronic databases: Scopus, Pubmed, $\mathrm{CAB}$ Abstract, Embase and Medline. The search terms used for searching in all databases were: “(West Nile Fever OR West Nile Virus) AND (Bird* OR Avian) AND (Mortality OR Sero-prevalence OR prevalence OR competence OR capacity OR transmission) AND (USA OR Canada)". All articles published from 1 January 1999 to 16 August 2017 (end of the search) were included in the selection process using criteria on the language, title, and abstract, as shown in Table 1. In short, selected studies had to be written in English or French, dealing with an epidemiological content about bird susceptibility (host competence, WNV-induced mortality, etc.) to WNV in Canada or the United States. Data on sero-prevalence and host competence were extracted from the retrieved publications. To rank birds species belonging to $L_{3}$, the standardized WNV sero-positive ratio, or relative ratio, $R R_{S}$, for each bird species "s" was calculated as, $R R_{s}=m_{s} /\left(\lambda \times n_{s}\right)$, where $m_{s}$ is the number of WNV sero-positive birds of species "s", $n_{s}$ is the sample size of the tested birds and $\lambda=\sum_{s} m_{s} / \sum_{s} n_{s}$ is the sero-positive rate under the homogeneous hypothesis; $\left(\lambda \times n_{s}\right)$ is the expected number of WNV sero-positive birds of species "s".

Migratory status (migratory $\mathrm{M}$, resident $\mathrm{R}$ birds or both $\mathrm{M}$ and $\mathrm{R}$ ) and wintering and breeding areas were also added for each bird species. Wintering/breeding areas were defined as the three main regions of the East Atlantic migration corridor: region of Québec QC, North USA and South USA, delimited by the northern border of the states of North Carolina and Tennessee [38]. The two US areas make it possible to take into account short and long distance migration. The migratory status of bird species allowed us to account for the possible geographic origin of WNV infection (acquired in the wintering zone vs. breeding zone) and the possible role of each bird species in the dispersal of WNV in North America.

Table 1. Search strategy for the literature review.

\begin{tabular}{|c|c|c|c|}
\hline \multirow{2}{*}{ Question } & \multirow[t]{2}{*}{ Description } & \multicolumn{2}{|r|}{ Answer } \\
\hline & & No & Yes/Cannot Tell \\
\hline \multicolumn{4}{|c|}{ Level 1: Language } \\
\hline Q1 & $\begin{array}{l}\text { Is the paper written in English or French? } \\
\qquad \mathrm{L} 1=\mathrm{Q} 1 \text {; eligible for } \mathrm{L} 1=1\end{array}$ & 0 & 1 \\
\hline \multicolumn{4}{|c|}{ Level 2: Title } \\
\hline Q1 & Does the title mention West Nile terms? & 0 & 1 \\
\hline Q2 & Does the title mention bird terms? & 0 & 1 \\
\hline Q3 & $\begin{array}{l}\text { Does the title mention a region of study that is concerned (East Coast } \\
\text { USA and Canada)? }\end{array}$ & 0 & 1 \\
\hline Q4 & $\begin{array}{l}\text { Does the title mention terms relate to sero-prevalence, prevalence, } \\
\text { competence, capacity or transmission? } \\
\qquad \mathrm{L} 2=\mathrm{Q} 1 \times \mathrm{Q} 2(1+\mathrm{Q} 3+\mathrm{Q} 4) ; \text { eligible for } \mathrm{L} 2 \geq 1\end{array}$ & 0 & 1 \\
\hline
\end{tabular}


Table 1. Cont.

\begin{tabular}{cccc}
\hline \multirow{2}{*}{ Question } & Description & Answer \\
\cline { 2 - 4 } & Level 3: Abstract & No & Yes/Cannot Tell \\
\hline Q1 & Does the abstract describe search results rather than a method? & 0 & 1 \\
Q2 & Do the abstract mention terms related to bird mortality? & 0 & 1 \\
Q3 & Do the abstract mention terms related to prevalence or & 0 & 1 \\
Q4 & Does the abstract mention terms relate to host competence ${ }^{1}$ ? & 0 & 1 \\
Q5 & Does the abstract mention terms relate to host capacity ${ }^{2}$ ? & 0 & 1 \\
Q6 & Does the abstract specify the regions of study: states of the Eastern & 0 & 1 \\
& migratory corridor for the USA and Canada? & & \\
\hline
\end{tabular}

${ }^{1}$ The host competence designates the capability of a given bird species of being infected and developing a sufficient viremia for transmitting infectious agents to vectors [39]. ${ }^{2}$ The concept of host capacity brings subtlety to the skill of the host. A competent bird species can only be involved in the transmission of the virus if it is sufficiently abundant and belongs to the species on which a mosquito competent for WNV feeds [34].

\section{Results}

\subsection{Wild Bird Mortality Data: List $L_{1}$}

Data from the passive WNV wild bird surveillance are reported below providing Characteristics of bird species, column "Mortality". We found a list $L_{1}=18$ that was sorted based on the relative ratio of dead birds positive for WNV, as shown in Figure 3. Of all these bird species, only two (Bald eagle and Blue jay) were under-represented (with the relative ratio of mortality $<1$ ) in mortality data.

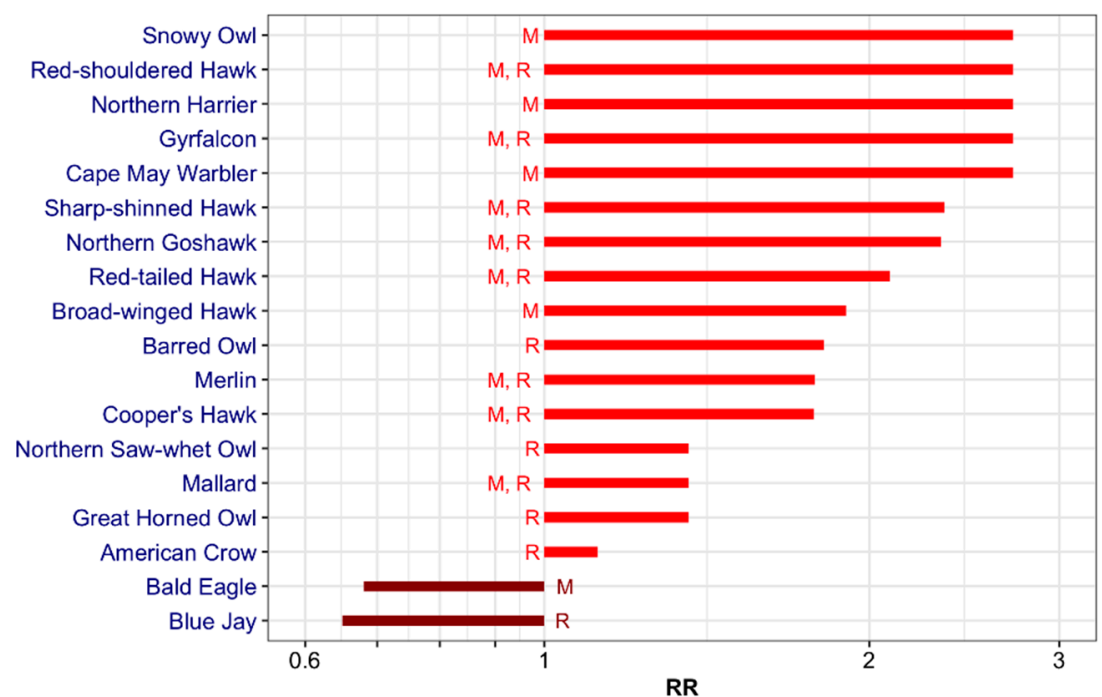

Figure 3. List $L_{1}$ : ranked list $(n=18)$ of dead birds found by WNV passive bird surveillance. RR stands for relative risk or ratio of dead birds found positive for WNV. Quoted letters " $M$ " and " $R$ " stand for migratory and resident birds, respectively.

\subsection{Blood Meal Analysis: List $\mathrm{L}_{2}$}

DNA from 273 engorged mosquitoes was extracted, although only 263 were included in the study as ten did not have a sufficient volume of DNA for amplification with both primer sets. In total, 97 out of 263 (36.9\%) were positive using PCR and sequencing with avian primers, whereas 14 out of 263 (5.3\%) were positive with PCR and sequencing using mammalian primers. Moreover, 10 out of 263 
extracts (four positives with avian primers and six positives with mammalian primers) were reported as indeterminate, as sequencing of the PCR product was not successful and there was insufficient volume remaining for repeat testing, as shown in Table 2.

Table 2. Results of the molecular analysis of blood meals.

\begin{tabular}{|c|c|c|c|c|c|c|}
\hline Species & Family & Order & $n$ & $\begin{array}{c}\text { Birds }(\%) \\
(n=97)\end{array}$ & $\begin{array}{l}\text { Mammals } \\
(\%)(n=14)\end{array}$ & $\begin{array}{c}\text { Total (\%) } \\
(n=111) *\end{array}$ \\
\hline \multicolumn{7}{|c|}{ Birds } \\
\hline Common starling (Sturnus vulgaris) & Sturnidae & Passeriformes & 11 & 11.3 & - & 9.9 \\
\hline Song sparrow (Melospiza melodia) & Emberizidae & Passeriformes & 9 & 9.3 & - & 8.1 \\
\hline Cedar waxwing (Bombycilla cedrorum) & Bombycillidae & Passeriformes & 8 & 8.2 & - & 7.2 \\
\hline Northern cardinal (Cardinalis cardinalis) & Cardinalidae & Passeriformes & 3 & 3.1 & - & 2.7 \\
\hline Gray catbird (Dumetella carolinensis) & Mimidae & Passeriformes & 3 & 3.1 & - & 2.7 \\
\hline House finch (Haemorhous mexicanus) & Fringillidae & Passeriformes & 3 & 3.1 & - & 2.7 \\
\hline Black-capped chickadee (Poecile atricapilla) & Paridae & Passeriformes & 3 & 3.1 & - & 2.7 \\
\hline Red-winged blackbird (Agelaius phoeniceus) & Icteridae & Passeriformes & 2 & 2.1 & - & 1.8 \\
\hline Northern flicker (Colaptes auratus) & Picidae & Piciformes & 1 & 1.0 & - & 0.9 \\
\hline American crow (Corvus brachyrhynchos) & Corvidae & Passeriformes & 1 & 1.0 & - & 0.9 \\
\hline American yellow warbler (Dendroica petechia) & Parulidae & Passeriformes & 1 & 1.0 & - & 0.9 \\
\hline Ovenbird (Seiurus aurocapilla) & Parulidae & Passeriformes & 1 & 1.0 & - & 0.9 \\
\hline American goldfinch (Spinus tristis) & Fringillidae & Passeriformes & 1 & 1.0 & - & 0.9 \\
\hline Chipping sparrow (Spizella passerina) & Emberizidae & Passeriformes & 1 & 1.0 & - & 0.9 \\
\hline Warbling vireo (Vireo gilvus) & Vireonidae & Passeriformes & 1 & 1.0 & - & 0.9 \\
\hline Mourning dove (Zenaida macroura) & Columbidae & Passeriformes & 1 & 1.0 & - & 0.9 \\
\hline \multicolumn{7}{|c|}{ Mammals } \\
\hline White-tailed deer (Odocoileus virginianus) & Cervidae & Artiodactyla & 7 & - & 50.0 & 6.3 \\
\hline Bovine (Bos taurus) & Bovidae & Artiodactyla & 2 & - & 14.3 & 1.8 \\
\hline
\end{tabular}

${ }^{*}$ of the 273 blood meal samples analyzed, 111 resulted in interpretable sequencing while 162 did not.

Twenty-three $\left(L_{2}=23\right)$ different bird species were identified as hosts for CPR mosquitoes, as shown in Figure 4. Most bitten bird species (with relative feeding $\geq 1$ ) belonged to the Passeriformes order, with the American robin $(31 \% ; n=30)$ being the most commonly identified, followed by the Common starling $(11.3 \% ; n=11)$, the Song sparrow $(9.3 \% ; n=9)$ and the Cedar waxwing $(8.2 \%$; $n=8$ ), as shown in Figure 4 in the left panel. A large proportion of the bird species (13 out of 23) were represented by only one or two blood meals. White-tailed deer were the most bitten mammal species, while two blood meals were from humans in weeks 27 (first week of July) and 32 (first week of August). Likewise, from the data in Table 3, the most abundant birds (with relative abundance $\geq 1$ ) were Common starling (21\%) and Red-winged blackbird (10\%), followed by Cedar waxwing, American goldfinch, Chipping sparrow, American robin and American crow (all with 6\%), as shown in Figure 4 in the left panel.

To explore the feeding preference of CPR, the list $L_{2}$ was sorted based on the value of $p_{s}$, as shown in Figure 4 in the right panel. Of these, the highest ranked species (with relative feeding preference $\geq$ 1) were (descending order): Common starling, American robin, Song sparrow and House sparrow. All other bird species were associated with a relative feeding preference lower than 1, suggesting that, while very abundant (as with Red-winged blackbirds), these species are not fed upon by CPR mosquitoes, as shown in Figure 4. 
Table 3. Characteristics of bird species affected by WNV in the Montréal area.

\begin{tabular}{|c|c|c|c|c|c|c|c|c|c|c|c|c|}
\hline \multirow[b]{2}{*}{ Family } & \multirow{2}{*}{$\begin{array}{l}\text { Species (English } \\
\text { Name) }\end{array}$} & \multirow{2}{*}{$\begin{array}{l}\text { Species (Latin } \\
\text { Name) }\end{array}$} & \multicolumn{2}{|c|}{ Literature } & \multicolumn{2}{|c|}{ Mortality, $\%(n)^{3}$} & \multirow[t]{2}{*}{$\begin{array}{c}\text { Abundance }^{4} \\
a_{s}\end{array}$} & \multirow[t]{2}{*}{$\begin{array}{c}\text { CPRfeeding }^{5} \\
f_{s}\end{array}$} & \multirow[t]{2}{*}{ Status $^{6}$} & \multirow[t]{2}{*}{$\begin{array}{l}\text { Wintering } \\
\text { Area }^{7}\end{array}$} & \multirow[t]{2}{*}{$\begin{array}{c}\text { Breeding } \\
\text { Area }^{7}\end{array}$} & \multirow[t]{2}{*}{$\begin{array}{c}\text { Spring } \\
\text { Migratior }\end{array}$} \\
\hline & & & $\begin{array}{l}\text { Seroprevalence } \\
(\%)^{1} \operatorname{Min} \\
(n)-\operatorname{Max}(n)\end{array}$ & $\begin{array}{l}\text { Iost Competence } \\
{ }^{2} \text { Min-Max }\end{array}$ & 2001-2008 & 2009-2017 & & & & & & \\
\hline Anatidae & Canada Goose & Branta canadensis & $0.8(1038)-29(7)$ & $0.03-0.05$ & & & & & $\mathrm{M}, \mathrm{R}$ & $\mathrm{s}$ & $\mathrm{QC}, \mathrm{N}$ & March \\
\hline Anatidae & Wood Duck & Aix sponsa & $0(1)-2.5(12)$ & & & $0(1)$ & & & $\mathrm{M}, \mathrm{R}$ & $\mathrm{s}$ & $\mathrm{QC}, \mathrm{N}, \mathrm{S}$ & March \\
\hline Anatidae & Mallard ${ }^{\dagger}$ & Anas platyrhynchos & $8(13)-10.6$ (66) & $0.48-0.5$ & & $50(4)$ & & & $\mathrm{M}, \mathrm{R}$ & $\mathrm{s}$ & $\mathrm{QC}, \mathrm{N}, \mathrm{S}$ & March \\
\hline Anatidae & Ring-necked Duck & Aythya collaris & $5.3(19)$ & & & & & & $\mathrm{M}, \mathrm{R}$ & $\mathrm{s}$ & $\mathrm{QC}, \mathrm{N}$ & March \\
\hline Ardeidae & Green Heron & Butorides virescens & $100(1)$ & & & & 0.0049 & 0.0103 & $\mathrm{M}$ & $\mathrm{s}$ & $\mathrm{QC}, \mathrm{N}, \mathrm{S}$ & April \\
\hline Accipitridae & Northern Harriert & Circus cyaneus & & & & $100(1)$ & & & M & $\mathrm{QC}, \mathrm{N}, \mathrm{S}$ & $\mathrm{QC}, \mathrm{N}$ & March \\
\hline Accipitridae & Sharp-shinned Hawk + & Accipiter striatus & & & & $86.4(22)$ & & & $\mathrm{M}, \mathrm{R}$ & $\mathrm{QC}, \mathrm{N}, \mathrm{S}$ & $\mathrm{QC}, \mathrm{N}, \mathrm{S}$ & March \\
\hline Accipitridae & Cooper's Hawkt & Accipiter cooperii & $100(1)$ & & & $65.4(26)$ & 0.0036 & 0.0103 & $\mathrm{M}, \mathrm{R}$ & $\mathrm{QC}, \mathrm{N}, \mathrm{S}$ & $\mathrm{QC}, \mathrm{N}, \mathrm{S}$ & March \\
\hline Accipitridae & Northern Goshawkt & Accipiter gentilis & & & & $85.7(7)$ & & & $\mathrm{M}, \mathrm{R}$ & $\mathrm{QC}, \mathrm{N}$ & $\mathrm{QC}, \mathrm{N}$ & March \\
\hline Accipitridae & Bald Eaglet & Haliaeetus leucophalus & & & & $25(4)$ & & & $\mathrm{M}$ & $\mathrm{N}, \mathrm{S}$ & $\mathrm{QC}, \mathrm{N}, \mathrm{S}$ & March \\
\hline Accipitridae & Red-shouldered Hawkt & Buteo lineatus & $100(1)$ & & & $100(5)$ & & & $\mathrm{M}, \mathrm{R}$ & $\mathrm{QC}, \mathrm{N}, \mathrm{S}$ & $\mathrm{QC}, \mathrm{N}, \mathrm{S}$ & March \\
\hline Accipitridae & Broad-winged Hawkt & Buteo platypterus & & & & $70(10)$ & & & $\mathrm{M}$ & $\mathrm{S}$ & $\mathrm{QC}, \mathrm{N}, \mathrm{S}$ & April \\
\hline Accipitridae & Red-tailed Hawkt & Buteo jamaicensis & & & & $76.9(13)$ & 0.0013 & & $\mathrm{M}, \mathrm{R}$ & $\mathrm{QC}, \mathrm{N}, \mathrm{S}$ & $\mathrm{QC}, \mathrm{N}, \mathrm{S}$ & March \\
\hline Charadriidae & Killdeer & Charadrius vociferus & & $0.84-0.87$ & & & & & $\mathrm{M}$ & $\mathrm{N}, \mathrm{S}$ & $\mathrm{QC}, \mathrm{N}, \mathrm{S}$ & March \\
\hline Laridae & Ring-billed Gull & Larus delawarensis & & $1.18-1.26$ & & $0(3)$ & & & $\mathrm{M}, \mathrm{R}$ & $\mathrm{QC}, \mathrm{N}, \mathrm{S}$ & $\mathrm{QC}, \mathrm{N}$ & February \\
\hline Columbidae & Rock Pigeon & Columba livia & $4.3(23)-55(20)$ & 0 & & & & & $\mathrm{R}$ & $\mathrm{QC}, \mathrm{N}, \mathrm{S}$ & $\mathrm{QC}, \mathrm{N}, \mathrm{S}$ & \\
\hline Columbidae & Mourning Dove & Zenaida macroura & $3.8(26)-57.69(26)$ & $0-0.19$ & & $0(2)$ & 0.0137 & 0.0103 & $\mathrm{M}, \mathrm{R}$ & $\mathrm{QC}, \mathrm{N}, \mathrm{S}$ & $\mathrm{QC}, \mathrm{N}, \mathrm{S}$ & April \\
\hline Cuculidae & $\overline{\text { Yellow-billed Cuckoo }}$ & Coccyzus americanus & $5.9(17)-100(1)$ & & & & & & $\mathrm{M}$ & & $\mathrm{QC}, \mathrm{N}, \mathrm{S}$ & Mai \\
\hline Strigidae & Great Horned Owlt & Bubo virginianus & $44.4(9)$ & $0.68-0.9$ & & $50(6)$ & & & $\mathrm{R}$ & $\mathrm{QC}, \mathrm{N}, \mathrm{S}$ & $\mathrm{QC}, \mathrm{N}, \mathrm{S}$ & \\
\hline Strigidae & Snowy Owlt & Bubo scandiacus & & & & $100(2)$ & & & $\mathrm{M}$ & $\mathrm{QC}, \mathrm{N}$ & & March \\
\hline Strigidae & Barred Owlt & Strix varia & & & & $66.7(3)$ & & & $\mathrm{R}$ & $\mathrm{QC}, \mathrm{N}, \mathrm{S}$ & $\mathrm{QC}, \mathrm{N}, \mathrm{S}$ & \\
\hline Strigidae & $\begin{array}{l}\text { Northern Saw-whet } \\
\text { Owlt }\end{array}$ & Aegolius acadicus & & & & $50(8)$ & & & $\mathrm{R}$ & $\mathrm{QC}, \mathrm{N}$ & $\mathrm{QC}, \mathrm{N}$ & \\
\hline Picidae & Hairy Woodpecker & Picoides villosus & $0(14)-14.3(7)$ & & & & & & $\mathrm{R}$ & $\mathrm{QC}, \mathrm{N}, \mathrm{S}$ & $\mathrm{QC}, \mathrm{N}, \mathrm{S}$ & \\
\hline Picidae & Northern Flicker & Colaptes auratus & & $0.06-0.14$ & & & 0.0178 & 0.0103 & $\mathrm{M}, \mathrm{R}$ & $\mathrm{N}, \mathrm{S}$ & $\mathrm{QC}, \mathrm{N}, \mathrm{S}$ & April \\
\hline Picidae & Pileated Woodpecker & Dryocopus pileatus & $20(5)$ & & & & & & $\mathrm{R}$ & $\mathrm{QC}, \mathrm{N}, \mathrm{S}$ & $\mathrm{QC}, \mathrm{N}, \mathrm{S}$ & \\
\hline Falconidae & American Kestrel & Falco sparverius & $16(152)-100(1)$ & $0.79-0.93$ & $0(1)$ & $0(5)$ & & & $\mathrm{M}, \mathrm{R}$ & $\mathrm{QC}, \mathrm{N}, \mathrm{S}$ & $\mathrm{QC}, \mathrm{N}, \mathrm{S}$ & April \\
\hline Falconidae & Merlint & Falco columbarius & $100(1)$ & & & $65.5(55)$ & & & $\mathrm{M}, \mathrm{R}$ & $\mathrm{QC}, \mathrm{N}, \mathrm{S}$ & $\mathrm{QC}, \mathrm{N}$ & March \\
\hline Falconidae & Gyrfalcont & Falco rusticolus & & & & $100(1)$ & & & $\mathrm{M}, \mathrm{R}$ & $\mathrm{QC}$ & & \\
\hline Tyrannidae & $\begin{array}{l}\text { Great Crested } \\
\text { Flycatcher }\end{array}$ & Myiarchus crinitus & $2(50)$ & & & & & & M & & $\mathrm{QC}, \mathrm{N}, \mathrm{S}$ & May \\
\hline Vireonidae & Warbling vireo & Vireo gilvus & & & & & 0.0189 & 0.0103 & M & & $\mathrm{QC}, \mathrm{N}, \mathrm{S}$ & May \\
\hline Vireonidae & Red-eyed vireo & Vireo olivaceus & & & & & 0.0288 & 0.0206 & $\mathrm{M}$ & & $\mathrm{QC}, \mathrm{N}, \mathrm{S}$ & May \\
\hline Corvidae & Blue Jay† & Cyanocitta cristata & $0.8(121)-35.8(134)$ & $2.39-2.55$ & $\begin{array}{l}23.6 \\
(886)\end{array}$ & $66.7(6)$ & 0.0093 & & $\mathrm{R}$ & $\mathrm{QC}, \mathrm{N}, \mathrm{S}$ & $\mathrm{QC}, \mathrm{N}, \mathrm{S}$ & \\
\hline Corvidae & $\underline{\text { American Crow }}^{+}$ & Corvus brachyrhynchos & $3.2(157)-68.3(183)$ & $1.04-1.62$ & $\begin{array}{c}40.1 \\
(1418)\end{array}$ & $73.9(46)$ & 0.0549 & 0.0103 & $\mathrm{R}$ & $\mathrm{QC}, \mathrm{N}, \mathrm{S}$ & $\mathrm{QC}, \mathrm{N}, \mathrm{S}$ & \\
\hline Hirundinidae & Tree Swallow & Tachycineta bicolor & $2.6(156)$ & & & & & & M & $\mathrm{s}$ & $\mathrm{QC}, \mathrm{N}, \mathrm{S}$ & March \\
\hline Paridae & Black-capped Chickadee & Poecile atricapillus & 0 (107) & & & & 0.0511 & 0.0309 & $\mathrm{R}$ & $\mathrm{QC}, \mathrm{N}$ & $\mathrm{QC}, \mathrm{N}$ & \\
\hline Sittidae & $\begin{array}{l}\text { White-breasted } \\
\text { Nuthatch }\end{array}$ & Sitta carolinensis & $0(40)-2.9(35)$ & & & & & & $\mathrm{R}$ & $\mathrm{QC}, \mathrm{N}, \mathrm{S}$ & $\mathrm{QC}, \mathrm{N}, \mathrm{S}$ & \\
\hline
\end{tabular}


Table 3. Cont

\begin{tabular}{|c|c|c|c|c|c|c|c|c|c|c|c|c|}
\hline \multirow{2}{*}{ Family } & \multirow{2}{*}{$\begin{array}{l}\text { Species (English } \\
\text { Name) }\end{array}$} & \multirow{2}{*}{$\begin{array}{l}\text { Species (Latin } \\
\text { Name) }\end{array}$} & \multicolumn{2}{|l|}{ Literature } & \multicolumn{2}{|c|}{ Mortality, $\%(n)^{3}$} & \multirow[t]{2}{*}{$\begin{array}{c}\text { Abundance }^{4} \\
a_{s}\end{array}$} & \multirow[t]{2}{*}{$\begin{array}{c}\text { CPRfeeding }^{5} \\
f_{s}\end{array}$} & \multirow[t]{2}{*}{ Status ${ }^{6}$} & \multirow[t]{2}{*}{$\begin{array}{c}\text { Wintering } \\
\text { Area }^{7}\end{array}$} & \multirow[t]{2}{*}{$\begin{array}{c}\text { Breeding } \\
\text { Area }{ }^{7}\end{array}$} & \multirow[t]{2}{*}{$\begin{array}{c}\text { Spring } \\
\text { Migration }\end{array}$} \\
\hline & & & $\begin{array}{cr}\text { Seroprevalence } & \\
(\%)^{1} & \text { Host } \\
\operatorname{Min}(n)-\operatorname{Max}(n) & \end{array}$ & $\begin{array}{l}\text { ost Competence } \\
{ }^{2} \text { Min-Max }\end{array}$ & 2001-2008 & 2009-2017 & & & & & & \\
\hline Troglodytidae & House Wren & Troglodytes aedon & $5.9(17)$ & & & & & & $\mathrm{M}$ & $\mathrm{s}$ & $\mathrm{QC}, \mathrm{N}, \mathrm{S}$ & April \\
\hline Turdidae & Eastern Bluebird & Sialia sialis & $2.4(126)$ & & & & & & $\mathrm{M}, \mathrm{R}$ & N.S & $\mathrm{QC}, \mathrm{N}, \mathrm{S}$ & March \\
\hline Turdidae & Swainson's Thrush & Catharus ustulatus & $2.13(47)-3.1(32)$ & & & & & & M & & QC, N & May \\
\hline Turdidae & Wood Thrush & Hylocichla mustelina & $1(101)-15.6(32)$ & & & & & & $\mathrm{M}$ & & $\mathrm{QC}, \mathrm{N}, \mathrm{S}$ & May \\
\hline Turdidae & American Robin & Turdus migratorius & $2.6(76)-10.11(366)$ & $1.04-1.1$ & & & 0.0578 & 0.3093 & $\mathrm{M}, \mathrm{R}$ & $\mathrm{QC}, \mathrm{N}, \mathrm{S}$ & $\mathrm{QC}, \mathrm{N}, \mathrm{S}$ & April \\
\hline Mimidae & $\overline{\text { Gray Catbird }}$ & Dumetella carolinensis & $3.5(2706)-35(17)$ & $0.07-0.1$ & & & 0.0158 & 0.0309 & $\mathrm{M}, \mathrm{R}$ & $\mathrm{N}, \mathrm{S}$ & $\mathrm{QC}, \mathrm{N}, \mathrm{S}$ & May \\
\hline Mimidae & Brown Thrasher & Toxostoma rufum & 3.7 (643)-10.5 (19) & & & & & & $\mathrm{M}, \mathrm{R}$ & $\mathrm{N}, \mathrm{S}$ & $\mathrm{QC}, \mathrm{N}, \mathrm{S}$ & April \\
\hline Sturnidae & Common Starling & Sturnus vulgaris & & $0.16-0.22$ & & & 0.2045 & 0.1134 & $\mathrm{R}$ & $\mathrm{QC}, \mathrm{N}, \mathrm{S}$ & $\mathrm{QC}, \mathrm{N}, \mathrm{S}$ & \\
\hline Bombycillidae & Cedar Waxwing & Bombycilla cedrorum & $20(5)$ & & & & 0.0671 & 0.0825 & $\mathrm{M}, \mathrm{R}$ & $\mathrm{QC}, \mathrm{N}, \mathrm{S}$ & $\mathrm{QC}, \mathrm{N}, \mathrm{S}$ & March \\
\hline Parulidae & Ovenbird & Seiurus aurocapilla & $0.9(115)-3.1(32)$ & & & & 0.0024 & 0.0103 & $\mathrm{M}$ & $\mathrm{s}$ & $\mathrm{QC}, \mathrm{N}, \mathrm{S}$ & May \\
\hline Parulidae & $\overline{\text { Common Yellowthroat }}$ & Geothlypis trichas & $0.7(299)$ & & & & & & $\mathrm{M}$ & $\mathrm{s}$ & $\mathrm{QC}, \mathrm{N}, \mathrm{S}$ & May \\
\hline Parulidae & American Redstart & Setophaga ruticilla & $0.4(280)$ & & & & & & $\mathrm{M}$ & $\mathrm{s}$ & $\mathrm{QC}, \mathrm{N}, \mathrm{S}$ & May \\
\hline Parulidae & Cape May Warbler † & Setophaga tigrina & & & & $100(1)$ & & & $\mathrm{M}$ & & $\mathrm{QC}, \mathrm{N}$ & May \\
\hline Parulidae & Northern Parula & Setophaga americana & $4.7(43)$ & & & & & & $\mathrm{M}$ & $\mathrm{s}$ & $\mathrm{QC}, \mathrm{N}, \mathrm{S}$ & May \\
\hline Parulidae & Yellow Warbler & Setophaga petechia & & 1 & & & 0.0368 & 0.0103 & $\mathrm{M}$ & & $\mathrm{QC}, \mathrm{N}, \mathrm{S}$ & April \\
\hline Passerellidae & Chipping Sparrow & Spizella passerina & $3(59)$ & & & & 0.0652 & 0.0103 & $\mathrm{M}, \mathrm{R}$ & $\mathrm{s}$ & $\mathrm{QC}, \mathrm{N}, \mathrm{S}$ & April \\
\hline Passerellidae & $\underline{\text { Savannah Sparrow }}$ & $\begin{array}{l}\text { Passerculus } \\
\text { sandwicheris }\end{array}$ & & & & & 0.0021 & 0.0412 & $\mathrm{M}$ & $\mathrm{s}$ & $\mathrm{QC}, \mathrm{N}$ & April \\
\hline Passerellidae & Song Sparrow & Melospiza melodia & $0(13)-3.4(88)$ & 1.2 & & & 0.0431 & 0.0928 & $\mathrm{M}, \mathrm{R}$ & $\mathrm{QC}, \mathrm{N}, \mathrm{S}$ & $\mathrm{QC}, \mathrm{N}, \mathrm{S}$ & April \\
\hline Passerellidae & Eastern Towhee & $\begin{array}{l}\text { Pipilo } \\
\text { eruthrophthalmus }\end{array}$ & 0.7 (144)-9.6 (197) & & & & & & M & $\mathrm{N}, \mathrm{S}$ & $\mathrm{QC}, \mathrm{N}, \mathrm{S}$ & April \\
\hline Cardinalidae & Scarlet Tanager & Piranga olivacea & $2.8(71)$ & & & & & & M & & $\mathrm{QC}, \mathrm{N}, \mathrm{S}$ & April \\
\hline Cardinalidae & Northern Cardinal & Cardinalis cardinalis & $6.2(503)-52.2(115)$ & 0.38 & & & 0.0313 & 0.0309 & $\mathrm{R}$ & $\mathrm{QC}, \mathrm{N}, \mathrm{S}$ & $\mathrm{QC}, \mathrm{N}, \mathrm{S}$ & \\
\hline Cardinalidae & $\overline{\text { Rose-breasted Grosbeak }}$ & $\begin{array}{l}\text { Pheucticus } \\
\text { ludovicianus }\end{array}$ & $1(98)-5(22)$ & & & & & & M & & $\mathrm{QC}, \mathrm{N}$ & April \\
\hline Cardinalidae & Indigo Bunting & Passerina cyanea & $3.6(28)-2.2(223)$ & & & & & & M & $\mathrm{s}$ & $\mathrm{QC}, \mathrm{N}, \mathrm{S}$ & April \\
\hline Icteridae & Eastern Meadowlark & Sturnella magna & 100 (1) & & & & & & $\mathrm{M}$ & $\mathrm{N}, \mathrm{S}$ & $\mathrm{QC}, \mathrm{N}, \mathrm{S}$ & March \\
\hline Icteridae & Baltimore Oriole & Icterus galbula & $8.3(12)$ & & & & & & $\mathrm{M}$ & $\mathrm{S}$ & $\mathrm{QC}, \mathrm{N}, \mathrm{S}$ & May \\
\hline Icteridae & $\underline{\text { Red-winged Blackbird }}$ & Agelaius phoeniceus & $0(63)-10.5(67)$ & $0.9-0.99$ & & & 0.1036 & 0.0206 & $\mathrm{M}, \mathrm{R}$ & $\mathrm{QC}, \mathrm{N}, \mathrm{S}$ & $\mathrm{QC}, \mathrm{N}, \mathrm{S}$ & March \\
\hline Icteridae & $\begin{array}{l}\text { Brown-headed } \\
\text { Cowbird }\end{array}$ & Molothrus ater & $1.8(494)-12.5(24)$ & 0 & & & & & $M, R$ & $\mathrm{QC}, \mathrm{N}, \mathrm{S}$ & $\mathrm{QC}, \mathrm{N}$ & April \\
\hline Icteridae & Common Grackle & Quiscalus quiscula & 0 (106)-15.4 (13) & $1.39-2.04$ & & & 0.0462 & 0.0206 & $\mathrm{M}, \mathrm{R}$ & $\mathrm{QC}, \mathrm{N}, \mathrm{S}$ & $\mathrm{QC}, \mathrm{N}, \mathrm{S}$ & March \\
\hline Fringillidae & House Finch & $\begin{array}{l}\text { Haemorhous } \\
\text { mexicanus }\end{array}$ & $2(927)-100(5)$ & $1.29-1.8$ & & & 0.0125 & 0.0309 & $\mathrm{M}, \mathrm{R}$ & $\mathrm{QC}, \mathrm{N}, \mathrm{S}$ & $\mathrm{QC}, \mathrm{N}, \mathrm{S}$ & March \\
\hline Fringillidae & American Goldfinch & Spinus tristis & $0.3(337)-3.1(128)$ & & & & 0.0666 & 0.0103 & $\mathrm{M}, \mathrm{R}$ & $\mathrm{QC}, \mathrm{N}, \mathrm{S}$ & $\mathrm{QC}, \mathrm{N}, \mathrm{S}$ & February \\
\hline Passeridae & House Sparrow & Passer domesticus & $1.6(1042)-51(107)$ & $1.25-1.6$ & & $0(1)$ & 0.0508 & 0.0722 & $\mathrm{R}$ & $\mathrm{QC}, \mathrm{N}, \mathrm{S}$ & $\mathrm{QC}, \mathrm{N}, \mathrm{S}$ & \\
\hline
\end{tabular}

Species = bird species for which blood meal data are available in our study area $(n=20) ; \dagger=$ bird species for which mortality data are available in available study area $(n=18) ;{ }^{1}$ Minimum and maximum percentages of WNV sero-positive birds ( $n=$ sample size) $[6,7,18,40-49] ;{ }^{2}$ Minimum and maximum index of host competence for WNV [20,50,51]; ${ }^{3}$ Percentage of dead birds positive for WNV ( $n=$ sample size) (CWHC). Data used in the construction of list $L_{1} ;{ }^{4} a_{s}$ is the density of species $s$ divided by the total density of the avian community-data come Migratory bird species; R: Resident bird species; ${ }^{7}$ S: South USA; N: North USA; QC: Québec. 

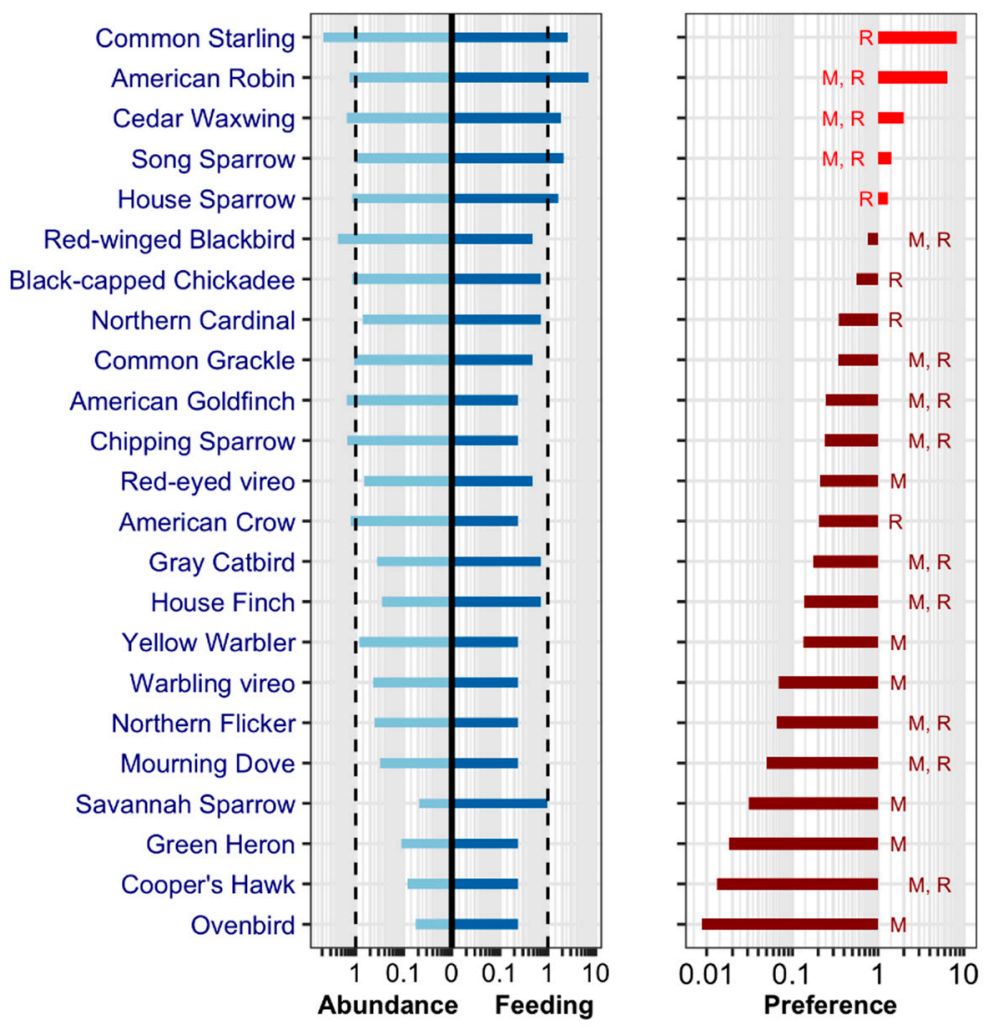

Figure 4. List $L_{2}$ : ranked list $(n=23)$ of bird species found from analysis of Culex pipiens-restuans (CPR) blood meals. Left panel: Relative abundance $\left(n \times a_{S}\right)$ of bird species and relative feeding (fraction of CPR blood meals) $\left(n \times f_{S}\right)$. Dashed vertical lines at relative abundance and feeding " 1 " represent the ratio " $1 / n$ " where $n=23$ is the bird species diversity. Right panel: relative host preference $\left(n \times p_{S}\right)$ of $C P R$. Quoted letters " $\mathrm{M}$ " and " $\mathrm{R}$ " stand for migratory and resident birds, respectively.

Analysis of Seasonal Bird-To-Mammal Feeding Shift of CPR Mosquitoes

There was a significant shift in the proportion of blood meals obtained from mammals compared to birds over the season (coefficient $=-0.27(95 \%$ confidence interval $=-0.47 ;-0.06), p<0.01)$. The shift appeared to be gradual and continuous from week 26 onwards, with an odds ratio of change in the proportion of blood meals from birds of $0.76(95 \%$ confidence interval $=0.62-0.94)$ per week, as shown in Figure 5.

\subsection{Literature Review: List $L_{3}$}

The literature search identified a total of 1244 articles, 23 of which met the selection criteria, as shown in Figure 6. As a result, we found a list $L_{3}=53$ that was sorted based on the relative ratio of sero-positives, as shown in Figure 7, as follows: 22 bird species were found most often sero-positive for WNV (with the relative ratio of sero-positives $\geq 1$ ) and the top five species were Red-shouldered hawk, Merlin, Green heron, Eastern meadowlark and Cooper's hawk (all with the same ratio of about 4). Conversely, 31 bird species rarely had serological evidence of exposure to WNV with American redstart having the lowest sero-prevalence. 


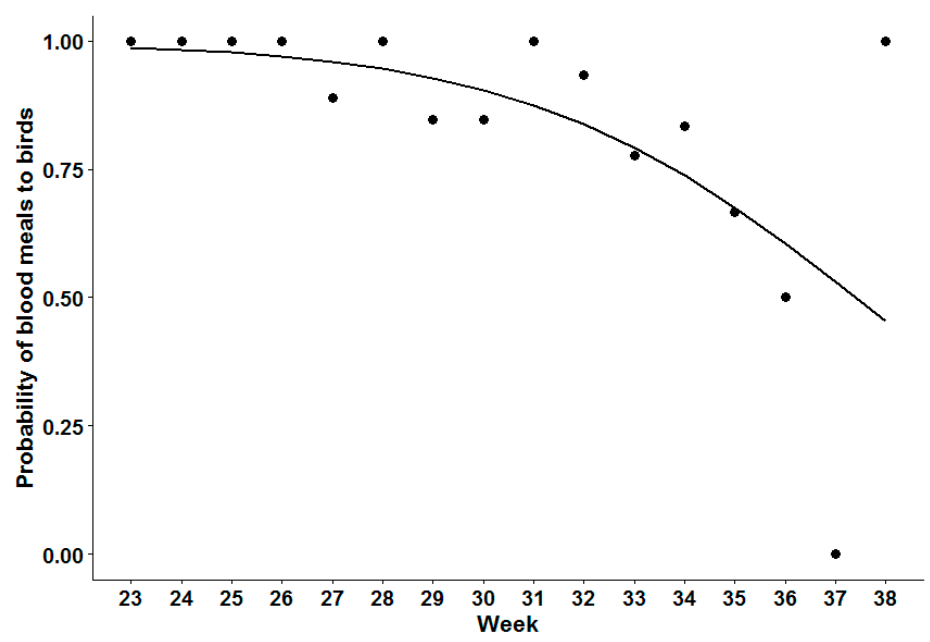

Figure 5. Weekly proportion of Culex pipiens-restuans blood meals taken from birds of all species. Data points correspond to field data and the solid line through the data corresponds to the predicted proportions using the logistic regression model.

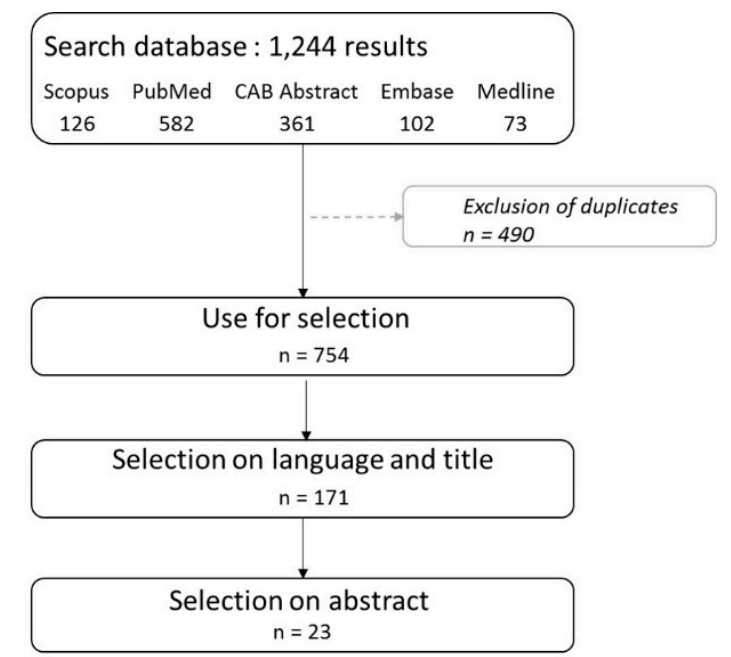

Figure 6. Selection process of articles and the result of the literature review.

\subsection{Final List: $L_{f}$}

The distribution of the species we identified among the lists is as follows: $L_{1}=18$ (mortality data of wild birds), $L_{2}=23$ (blood meal analysis of the CPR) and $L_{3}=53$ (literature review) with the number of common species, $L_{1} \cap L_{2}=2, L_{1} \cap L_{3}=7$ and $L_{2} \cap L_{3}=20$, and $L_{1} \cap L_{2} \cap L_{3}=2$ species (American crow and Cooper's hawk) belonging to all three lists. The final list of 67 bird species was obtained as, $67=\left[L_{1}+L_{2}+L_{3}-L_{1} \cap L_{2}-L_{1} \cap L_{3}-L_{2} \cap L_{3}+L_{1} \cap L_{2} \cap L_{3}\right]=18+23+53-2-7-20+2$, representing $21 \%$ of $L_{0}=318$ species from the Avibase database [27], which includes all the species present in the Montréal area. Table 3 presents the summary results of the characteristics of each of the selected 67 bird species of interest. Characteristic variables include data on bird mortality, bird abundance, CPR feeding preference and sero-prevalence for WNV, host competence, migratory status and sites for wintering and breeding extracted from the literature. 


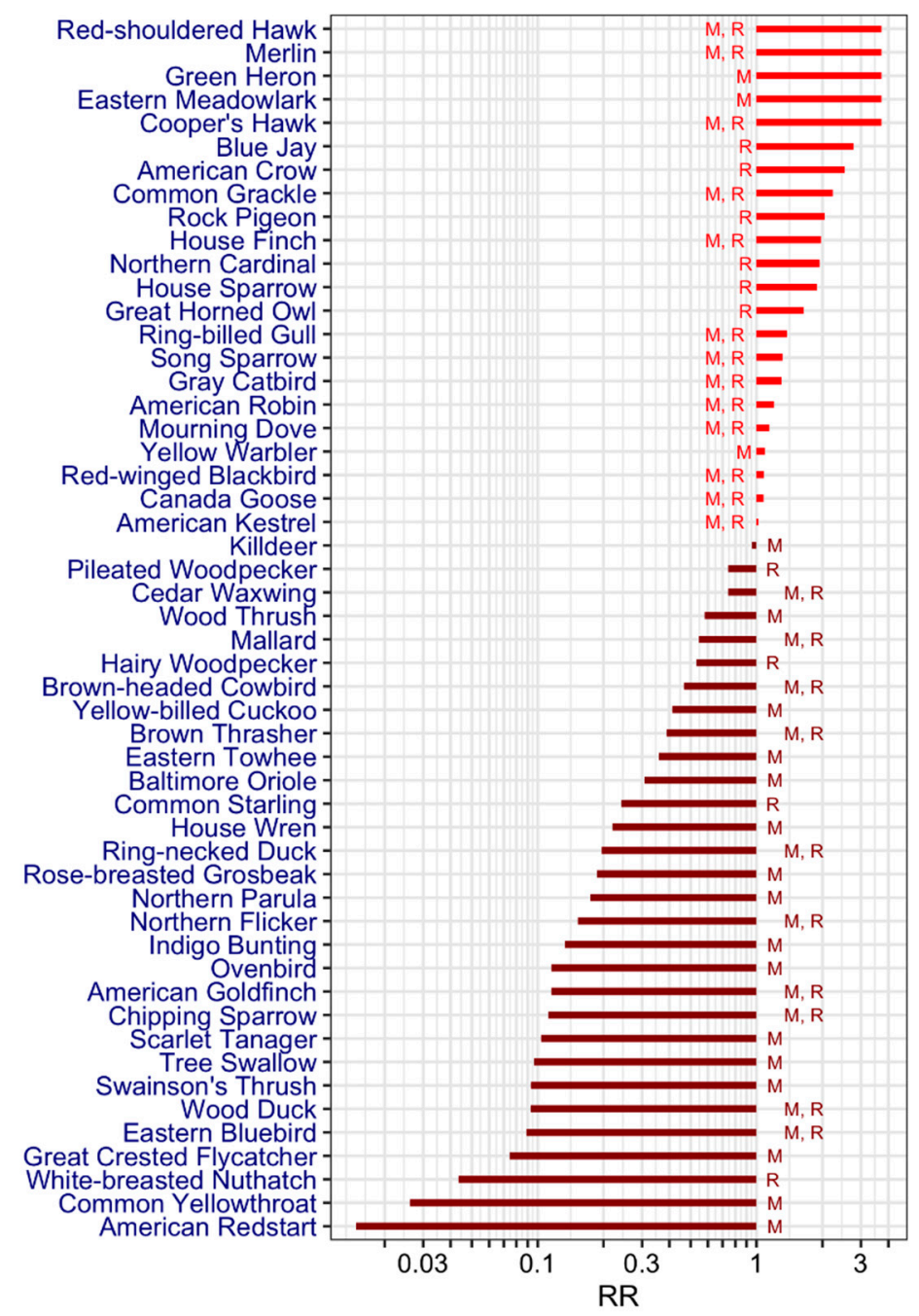

Figure 7. List $L_{3}$ : ranked list $(n=53)$ of bird species found from the literature review. RR stands for relative risk or ratio of sero-positives. Quoted letters " $\mathrm{M}$ " and " $\mathrm{R}$ " stand for migratory and resident birds, respectively.

\section{Discussion}

In this study, we constructed a priority list of bird species potentially involved in the transmission of WNV in the greater Montréal region. We constructed this list by combining three sources of data: (i) results from WNV surveillance in wild (dead) birds in the province (2002-2015); (ii) evidence from molecular blood meal analysis that selected bird species are fed upon by CPR, the primary enzootic vectors of WNV in the region, collected in mosquito surveillance in the study area in 2008 and 2014; and (iii) a literature review on evidence for exposure to WNV (sero-prevalence) and the host competence of resident bird species. There were 67 breeding species identified by these data sources, which highlights the potential complexity of WNV transmission cycles in Québec.

Out of the 67 bird species, host competences were documented for 22 bird species, including eight highly competent (competence $>1$ ) bird species ranked as follows (from the most to the least competent): Blue jay, Common grackle, House finch, House sparrow, Song sparrow, American robin, American crow and Ring-billed gull. American crows and Blue jays were used as indicators of local WNV circulation at the beginning of the epidemics [52-54]. In addition, both of these species exhibit high viremia when infected [20], though mortality rates are high in both species. The mortality of infected birds shortens the overall period of virus transmission, but some infected bird species can 
maintain sufficiently high viremia to infect many mosquitoes during the time from disease onset to death. Not all bird species are susceptible to mortality from WVN. For example, WNV amplification in California is driven primarily by house finches, which rarely die from WNV infection, and Culex tarsalis as the main vector species [55].

Blood meal analysis data identified 23 bird species as potential hosts for CPR mosquitoes. Most bird species bitten by CPR mosquitoes were (from most to least preferred): Common startling, American robins, Cedar waxwing, Song sparrow and House sparrow. The preference of CPR to feed upon American robins has been reported in other studies (e.g., in $[13,56])$ and all species, except Cedar waxwings, are competent reservoirs for WNV in at least one study, as shown in Table 2. Bird species other than American robins likely play a role in WNV transmission, particularly as some, including some sparrow species, may have greater capacity to transmit WNV (due to longer duration and higher viremia) than American robins.

The role of the species other than American robins in the transmission of WNV could also be related to possible transmission by competent vectors other than CPR. In eastern Canada, for example, Aedes vexans, a widespread mosquito, is competent to transmit WNV, but it prefers to feed upon mammals and only occasionally feeds on birds $[11,57,58]$.

Other studies have found that House sparrows are under-represented as hosts for mosquitoes relative to their densities $[13,56]$, while in our study they appeared over-represented. To what extent these observations may be driven by regional factors, such as climate affecting bird population densities, or the relatively urbanized nature of the study area, requires further study. Mosquitoes that were collected as part of a routine entomological WNV surveillance in CO2-baited CDC light traps [11] and gravid traps, that purport to attract greater numbers of engorged mosquitoes [59], were not used. We could not rule out the possibility that this could affect comparisons with the results of studies in which gravid traps were used, although different findings using gravid and light traps regarding blood meals have not been reported [13].

We observed a shift in feeding behavior from birds to mammals, as reported in other studies [13,60,61]. Almost all CPR blood meals were taken from birds in early summer (week 23), while the ratio of bird to mammal blood meals started to decline around mid-July. However, as pointed out by others [56] the main shift in mosquito feeding from birds to mammals occurred in parallel with the onset of reported human cases (which, in Québec, usually happens during surveillance weeks 28-31 [62]. The date of acquisition of cases reported in human-case surveillance is likely several weeks before the date of reporting in surveillance [63], so while a shift of feeding behavior from birds to mammals (including humans) may contribute to the seasonal pattern of WNV infection in humans, it is unlikely to be the main cause.

\section{Conclusions}

These findings indicate a broad similarity in the ecology of WNV in the study region and regions in the US. We noted a similar range of key avian reservoir host species and seasonal change in host selection by mosquitoes. This work has shed light on the involvement of American robins and other bird species in the circulation of the WNV in southern Québec. However, the relative importance of some bird species as hosts of CPR and WNV in the greater Montréal area may be somewhat different to that occurring in northeastern US, and field studies are needed to confirm this and explore the consequences for the risk of WNV to the human population. In addition, studies both in the field and using modeling are necessary to elucidate the roles of each bird species, which would help to synthesize and consolidate knowledge regarding the eco-epidemiology of WNV in this area. These types of studies would allow us to improve the surveillance, control and management of WNV and possibly other vector-borne wildlife diseases, which are becoming increasingly important in North America [64-66]. 
Author Contributions: Conceptualization, A.L. and D.J.B.; methodology, D.J.B.; formal analysis, L.T.; data curation, L.T.; molecular analysis, R.L.L. and M.I.; writing-original draft preparation, L.T., A.L. and D.J.B.; writing-review and editing, L.T., A.L, N.H.O., R.L.L., M.I., C.A.G. and D.J.B.; supervision, A.L. and D.J.B. All authors have read and agreed to the published version of the manuscript.

Funding: This research received no external funding.

Acknowledgments: The authors thank all the workers from MSSS, RQO and CWHC who collected and reported the data used in this study. This study was funded by the Public Health Agency of Canada, ComUE-UGA and IDEX “Université Grenoble Alpes: Université de l'innovation”. CRIPA is a research center financially supported by the Fonds de recherche Québec Nature et Technologies (FRQNT).

Conflicts of Interest: The authors declare no conflict of interest.

\section{References}

1. Smithburn, K.C.; Hughes, T.P.; Burke, A.W.; Paul, J.H. A Neurotropic Virus Isolated from the Blood of a Native of Uganda1. Am. J. Trop. Med. Hyg. 1940, s1-s20, 471-492. [CrossRef]

2. Work, T.H.; Hurlbut, H.S.; Taylor, R.M. Isolation of West Nile virus from hooded crow and rock pigeon in the Nile delta. Proc. Soc. Exp. Biol. Med. 1953, 84, 719-722. [CrossRef] [PubMed]

3. Taylor, R.M.; Work, T.H.; Hurlbut, H.S.; Rizk, F. A Study of the Ecology of West Nile Virus in Egypt. Am. J. Trop. Med. Hyg. 1956, 5, 579-620. [CrossRef]

4. Petersen, L.R.; Brault, A.C.; Nasci, R.S. West Nile virus: Review of the literature. JAMA 2013, 310, 308-315. [CrossRef] [PubMed]

5. Garmendia, A.E.; Van Kruiningen, H.J.; French, R.A. The West Nile virus: Its recent emergence in North America. Microb. Infect. 2001, 3, 223-229. [CrossRef]

6. Komar, N.; Panella, N.A.; Boyce, E. Exposure of domestic mammals to West Nile virus during an outbreak of human encephalitis, New York City, 1999. Emerg. Infect. Dis. 2001, 7, 736-738. [CrossRef] [PubMed]

7. Komar, N.; Panella, N.A.; Burns, J.E.; Dusza, S.W.; Mascarenhas, T.M.; Talbot, T.O. Serologic evidence for West Nile virus infection in birds in the New York City vicinity during an outbreak in 1999. Emerg. Infect. Dis. 2001, 7, 621-625. [CrossRef] [PubMed]

8. Gancz, A.Y.; Campbell, D.G.; Barker, I.K.; Lindsay, R.; Hunter, B. Detecting West Nile Virus in Owls and Raptors by an Antigen-capture Assay. Emerg. Infect. Dis. 2004, 10, 2204-2206. [CrossRef]

9. INSPQ. Proposition d'un Programme de Surveillance Entomologique du Virus du Nil Occidental au Québec-Avis Scientifique; Institut National de Santé Publique du Québec: Quebec City, QC, Canada, 2015.

10. Dauphin, G.; Zientara, S.; Zeller, H.; Murgue, B. West Nile: Worldwide current situation in animals and humans. Comp. Immunol. Microbiol. Infect. Dis. 2004, 27, 343-355. [CrossRef]

11. Ripoche, M.; Ludwig, A.; Campagna, C.; Ludwig, A.; Ogden, N.H.; Leighton, P.A. Short-term Forecasting of Daily Abundance of West Nile Virus Vectors Culex pipiens-restuans (Diptera: Culicidae) and Aedes vexans Based on Weather Conditions in Southern Québec (Canada). J. Med. Entomol. 2019, 56, 859-872. [CrossRef]

12. Kilpatrick, A.M.; Daszak, P.; Jones, M.J.; Marra, P.P.; Kramer, L.D. Host heterogeneity dominates West Nile virus transmission. Proc. Biol. Sci. 2006, 273, 2327-2333. [CrossRef] [PubMed]

13. Kilpatrick, A.M.; Kramer, L.D.; Jones, M.J.; Marra, P.P.; Daszak, P. West Nile Virus Epidemics in North America Are Driven by Shifts in Mosquito Feeding Behavior. PLoS Biol. 2006, 4, e82. [CrossRef] [PubMed]

14. Andreadis, T.G. The contribution of Culex pipiens complex mosquitoes to transmission and persistence of West Nile virus in North America. J. Am. Mosq. Control Assoc. 2012, 28 (Suppl. 4), 137-151. [CrossRef] [PubMed]

15. Rappole, J.H.; Derrickson, S.R.; Hubalek, Z. Migratory birds and spread of West Nile virus in the Western Hemisphere. Emerg. Infect. Dis. 2000, 6, 319-328. [CrossRef] [PubMed]

16. Peterson, A.T.; Vieglais, D.A.; Andreasen, J.K. Migratory birds modeled as critical transport agents for West Nile Virus in North America. Vector-Borne Zoonotic Dis 2003, 3, 27-37. [CrossRef]

17. Jourdain, E.; Gauthier-Clerc, M.; Bicout, D.J.; Sabatier, P. Bird Migration Routes and Risk for Pathogen Dispersion into Western Mediterranean Wetlands. Emerg. Infect. Dis. 2007, 13, 365-372. [CrossRef]

18. Dusek, R.J.; McLean, R.G.; Kramer, L.D.; Ubico, S.R.; Dupuis, A.P.; Ebel, G.D.; Guptill, S.C. Prevalence of West Nile virus in migratory birds during spring and fall migration. Am. J. Trop. Med. Hyg. 2009, 81, 1151-1158. [CrossRef] 
19. Owen, J.C.; Nakamura, A.; Coon, C.A.; Martin, L.B. The effect of exogenous corticosterone on West Nile virus infection in Northern Cardinals (Cardinalis cardinalis). Vet. Res. 2012, 43, 34. [CrossRef]

20. Komar, N.; Langevin, S.; Hinten, S.; Nemeth, N.; Edwards, E.; Hettler, D.L.; David, B.S.; Bowen, R.A.; Bunning, M.L. Experimental Infection of North American Birds with the New York 1999 Strain of West Nile Virus. Emerg. Infect. Dis. 2003, 9, 311-322. [CrossRef]

21. Marra, P.; Griffing, S.; Caffrey, C.; Kilpatrick, A.; McLean, R.; Brand, C.; Saito, E.; Dupuis, A.; Kramer, L.; Novak, R. West Nile Virus and Wildlife. BioScience 2004, 54, 393-402. [CrossRef]

22. Thomas-Bachli, A.L.; Pearl, D.L.; Berke, O.; Parmley, E.J.; Barker, I.K. A comparison of West Nile virus surveillance using survival analyses of dead corvid and mosquito pool data in Ontario, 2002-2008. Prev. Vet. Med. 2015, 122, 363-370. [CrossRef] [PubMed]

23. Veksler, A.; Eidson, M.; Zurbenko, I. Assessment of methods for prediction of human West Nile virus (WNV) disease from WNV-infected dead birds. Emerg. Themes Epidemiol. 2009, 6, 4. [CrossRef] [PubMed]

24. LaDeau, S.L.; Kilpatrick, A.M.; Marra, P.P. West Nile virus emergence and large-scale declines of North American bird populations. Nature 2007, 447, 710-713. [CrossRef] [PubMed]

25. Fougères, D.; Macleod, R. Montreal: The History of a North American City; McGill-Queen's University Press: Montreal, QC, Canada, 2017.

26. StatisticsCanada. Land Cover and Land Use Montreal. 2016. Available online: http://www.statcan.gc.ca/ pub/16-201-x/2016000/c-g/c-g03-29-eng.htm (accessed on 17 June 2019).

27. Lepage, D. Avibase-Listes D'oiseaux Mondiales Montérégie: Montréal. 2017. Available online: https: //avibase.bsc-eoc.org/checklist.jsp?region=caqc05\&list=howardmoore\&lang=FR (accessed on 21 May 2020).

28. Drebot, M.A.; Lindsay, R.; Barker, I.K.; Buck, P.A.; Fearon, M.; Hunter, F.; Sockett, F.; Artsob, H. West Nile virus surveillance and diagnostics: A Canadian perspective. Can. J. Infect. Dis. 2003, 14, 105-114. [CrossRef]

29. Lindsay, R.; Barker, I.; Nayar, G.; Drebot, M.; Calvin, S.; Scammell, C.; Sachvie, C.; La Fleur, T.; Dibernardo, A.; Andonova, M.; et al. Rapid Antigen-Capture Assay To Detect West Nile Virus in Dead Corvids. Emerg. Infect. Dis. 2003, 9, 1406-1410. [CrossRef] [PubMed]

30. CWHC. Le Virus du Nil Occidental. 2016. Available online: http://fr.cwhc-rcsf.ca/west_nile_virus.php (accessed on 20 July 2016).

31. Molaei, G.; Thomas, M.C.; Muller, T.; Medlock, J.; Shepard, J.J.; Armstrong, P.M.; Andreadis, T.G. Dynamics of Vector-Host Interactions in Avian Communities in Four Eastern Equine Encephalitis Virus Foci in the Northeastern U.S. PLoS Negl. Trop. Dis. 2016, 10, e0004347. [CrossRef]

32. Rizzoli, A.; Bolzoni, L.; Chadwick, E.A.; Capelli, G.; Montarsi, F.; Grisenti, M.; de la Puente, J.M.; Munoz, J.; Figuerola, J.; Soriguer, R.; et al. Understanding West Nile virus ecology in Europe: Culex pipiens host feeding preference in a hotspot of virus emergence. Parasit. Vectors 2015, 8, 213. [CrossRef]

33. Balenghien, T.; Fouque, F.; Sabatier, P.; Bicout, D.J. Theoretical Formulation for Mosquito Host-Feeding Patterns: Application to a West Nile Virus Focus of Southern France. J. Med. Entomol. 2011, 48, 1076-1090. [CrossRef]

34. Bicout, D.J. Le virus du Nil occidental; Éditions Quæ: Versailles, France, 2013; p. 239.

35. Regroupement Québec Oiseaux. Etude des Populations d'oiseaux du Québec. 2018. Available online: https://www.oiseauxqc.org/epoq.jsp (accessed on 15 October 2018).

36. Farajollahi, A.; Fonseca, D.M.; Kramer, L.D.; Kilpatrick, A.M. "Bird biting” mosquitoes and human disease: A review of the role of Culex pipiens complex mosquitoes in epidemiology. Infect. Genet. Evolut. 2011, 11, 1577-1585. [CrossRef]

37. R Foundation for Statistical Computing. Available online: http://www.R-project.org (accessed on 21 May 2020).

38. Peterson, R.T.; Peterson, V.M. Les Oiseaux du Québec et de l'Est de l'Amérique du Nord, 5th ed.; Broquet: Saint-Constant, QC, Canada, 2004.

39. Komar, N.; Dohm, D.J.; Turell, M.J.; Spielman, A. Eastern equine encephalitis virus in birds: Relative competence of European starlings (Sturnus vulgaris). Am. J. Trop. Med. Hyg. 1999, 60, 387-391. [CrossRef]

40. Ringia, A.M.; Blitvich, B.J.; Koo, H.Y.; Van de Wyngaerde, M.; Brawn, J.D.; Novak, R.J. Antibody prevalence of West Nile virus in birds, Illinois, 2002. Emerg. Infect. Dis. 2004, 10, 1120-1124. [CrossRef] [PubMed]

41. Godsey, M.S., Jr.; Blackmore, M.S.; Panella, N.A.; Burkhalter, K.; Gottfried, K.; Halsey, L.A.; Rutledge, R.; Langevin, S.A.; Gates, R. West Nile virus epizootiology in the southeastern United States, 2001. Vector Borne Zoonotic Dis. 2005, 5, 82-89. [CrossRef] [PubMed] 
42. Komar, N.; Panella, N.A.; Langevin, S.A.; Brault, A.C.; Amador, M.; Edwards, E.; Owen, J.C. Avian hosts for West Nile virus in St. Tammany Parish, Louisiana, 2002. Am. J. Trop. Med. Hyg. 2005, 73, 1031-1037. [CrossRef]

43. Gibbs, S.E.; Allison, A.B.; Yabsley, M.J.; Mead, D.G.; Wilcox, B.R.; Stallknecht, D.E. West Nile virus antibodies in avian species of Georgia, USA: 2000-2004. Vector Borne Zoonotic Dis. 2006, 6, 57-72. [CrossRef]

44. Loss, S.R.; Hamer, G.L.; Walker, E.D.; Ruiz, M.O.; Goldberg, T.L.; Kitron, U.D.; Brawn, J.D. Avian host community structure and prevalence of West Nile virus in Chicago, Illinois. Oecologia 2009, 159, 415-424. [CrossRef]

45. Dubé, M.C.; Bird, D.M.; Dibernardo, A.; Lindsay, L.R.; Charest, H. Prevalence of West Nile virus in wild American Kestrels (Falco sparverius) of southern Quebec, Canada. J. Wildl. Dis. 2010, 46, 603-607. [CrossRef] [PubMed]

46. Chuang, T.W.; Knepper, R.G.; Stanuszek, W.W.; Walker, E.D.; Wilson, M.L. Temporal and spatial patterns of West Nile virus transmission in Saginaw County, Michigan, 2003-2006. J. Med. Entomol. 2011, 48, 1047-1056. [CrossRef] [PubMed]

47. Kilpatrick, A.M.; Peters, R.J.; Dupuis, A.P., 2nd; Jones, M.J.; Marra, P.P.; Kramer, L.D. Predicted and observed mortality from vector-borne disease in small songbirds. Biol. Conserv. 2013, 165, 79-85. [CrossRef]

48. Komar, N.; Panella, N.A.; Young, G.R.; Brault, A.C.; Levy, C.E. Avian hosts of West Nile virus in Arizona. Am. J. Trop. Med. Hyg. 2013, 89, 474-481. [CrossRef]

49. Randall, N.J.; Blitvich, B.J.; Blanchong, J.A. Association between agricultural land use and West Nile virus antibody prevalence in Iowa birds. J. Wildl. Dis. 2013, 49, 869-878. [CrossRef]

50. Kilpatrick, A.M.; LaDeau, S.L.; Marra, P.P. Ecology of West Nile Virus Transmission and its Impact on Birds in the Western Hemisphere. The Auk 2007, 124, 1121-1136. [CrossRef]

51. Wheeler, S.S.; Barker, C.M.; Fang, Y.; Armijos, M.V.; Carroll, B.D.; Husted, S.; Johnson, W.O.; Reisen, W.K. Differential impact of West Nile Virus on California birds. Condor 2009, 111, 1-20. [CrossRef] [PubMed]

52. Ludwig, A.; Bigras-Poulin, M.; Michel, P.; Belanger, D. Risk factors associated with West Nile virus mortality in American Crow populations in Southern Quebec. J. Wildl. Dis. 2010, 46, 195-208. [CrossRef] [PubMed]

53. Foppa, I.M.; Beard, R.H.; Mendenhall, I.H. The impact of West Nile virus on the abundance of selected North American birds. BMC Vet. Res. 2011, 7, 43. [CrossRef]

54. Thomas-Bachli, A.L.; Pearl, D.L.; Parmley, E.J.; Berke, O. The Influence of Sociodemographic Factors on the Engagement of Citizens in the Detection of Dead Corvids during the Emergence of West Nile Virus in Ontario, Canada. Front. Vet. Sci. 2020, 6, 483. [CrossRef] [PubMed]

55. Worwa, G.; Hutton, A.A.; Brault, A.C.; Reisen, W.K. Comparative fitness of West Nile virus isolated during California epidemics. PLoS Negl. Trop. Dis. 2019, 13, e0007135. [CrossRef]

56. Hamer, G.L.; Kitron, U.D.; Goldberg, T.L.; Brawn, J.D.; Loss, S.R.; Ruiz, M.O.; Hayes, D.B.; Walker, E.D. Host selection by Culex pipiens mosquitoes and west nile virus amplification. Am. J. Trop. Med. Hyg. 2009, 80, 268-278. [CrossRef]

57. Andreadis, T.G.; Anderson, J.F.; Vossbrinck, C.R.; Main, A.J. Epidemiology of West Nile virus in Connecticut: A five-year analysis of mosquito data 1999-2003. Vector Borne Zoonotic Dis. 2004, 4, 360-378. [CrossRef]

58. Giordano, B.V.; Turner, K.W.; Hunter, F.F. Geospatial Analysis and Seasonal Distribution of West Nile Virus Vectors (Diptera: Culicidae) in Southern Ontario, Canada. Int. J. Env. Res. Pub. Health 2018, 15. [CrossRef]

59. Silver, J.B. CHAP2: Sampling the Egg Population. In Mosquito Ecology_Field Sampling Methods, 3rd ed.; Springer: Dordrecht, the Netherlands, 2018; pp. 25-136.

60. Kilpatrick, A.M.; Kramer, L.D.; Campbell, S.R.; Alleyne, E.O.; Dobson, A.P.; Daszak, P. West Nile virus risk assessment and the bridge vector paradigm. Emerg. Infect. Dis. 2005, 11, 425-429. [CrossRef]

61. Kilpatrick, A.M.; Kramer, L.D.; Campbell, S.R.; Alleyne, E.O.; Dobson, A.P.; Daszak, P. Supersuppression: Reservoir Competency and Timing of Mosquito Host Shifts Combine to Reduce Spillover of West Nile Virus. Am. J. Trop. Med. Hyg. 2016, 95, 1174-1184. [CrossRef]

62. West Nile virus and other mosquito-borne diseases national surveillance report. Available online: https://www.canada.ca/en/public-health/services/diseases/west-nile-virus/west-nile-virus-othermosquito-borne-disease.html (accessed on 21 May 2020).

63. Ogden, N.H.; Ludwig, A.; Morse, A.P.; Zheng, H.; Zhu, H. Weather-based forecasting of mosquito-borne disease outbreaks in Canada. Can Commun. Dis. Rep. 2019, 45, 127-132. [CrossRef] [PubMed] 
64. McDonald, E.; Martin, S.W.; Landry, K.; Gould, C.V.; Lehman, J.; Fischer, M.; Lindsey, N.P. West Nile Virus and Other Domestic Nationally Notifiable Arboviral Diseases-United States, 2018. MMWR Morb. Mortal. Wkly. Rep. 2019, 68, 673-678. [CrossRef]

65. Ronca, S.E.; Murray, K.O.; Nolan, M.S. Cumulative Incidence of West Nile Virus Infection, Continental United States, 1999-2016. Emerg. Infect. Dis. 2019, 25, 325-327. [CrossRef]

66. Mermel, L.A. Association of Human Eastern Equine Encephalitis with Precipitation Levels in Massachusetts. JAMA Netw. Open 2020, 3, e1920261. [CrossRef] [PubMed] 